\title{
THE ROLE OF POLYCENTRIC NETWORK IN THE DEMOGRAPHIC DYNAMIC OF HUMAN SETTLEMENTS
}

\author{
Jean Baptiste HUMEAU ${ }^{1)}$, Daniel PEPTENATU ${ }^{2)}$, Radu PINTILII'), \\ Cristian DRĂGHICl ${ }^{2)}$, Andrei SCHVAB ${ }^{2)}$ \\ 1) University of Angers, France, \\ ${ }^{2)}$ University of Bucharest - Interdisciplinary Centre for Advanced \\ Researches on Territorial Dynamics, Romania
}

\begin{abstract}
The present study is a concise form of some of the researches conducted within the Interdisciplinary Centre for Advanced Researches on Territorial Dynamics of the University of Bucharest, which had as an objective identifying the relationships between the development of the poles network and the evolution of demographic indicators. The study's objectives are related to identifying the role of decisional impulses from the development poles level in the functional structuring of the local settlements system. The analyses were done at each census level, and the measures adopted by the decision makers in order to stimulate the economy of development poles were underlined. A special attention was given to the communist period, when decisional impulses were followed by immediate effects at the level of dissipative capacity of towns, towards which the investments allocated in order to develop industry were oriented.
\end{abstract}

Key Words: polycentric network, demographic dynamic, development poles, territorial management, innovation

\section{Introduction}

One of the major objectives of the European Union is reducing territorial disparities between the centre and the suburbs, an objective to be accomplished through the construction of networks that have the ability of distributing information from the supra-systems level to local level (Geppert K, Stephan A, 2008).

Trullén and Boix consider that the polycentrism is the population and economic activities' tendency to gather in urban nuclei, which start to diffuse influence upon settlements' networks, as well as upon its environment (Boix R, Trullén J, 2003a, 2007).

Territorial development based on several decision centres has seen important differences within the territory, through the distribution of demographic indicators, companies and use of land (Wu F, 1998, Wang X, Kockelman K. M, 2009). The introduction of the concept of polycentric development has led to substantial arguments in the scientific world, regarding the efficiency of the polycentric development model in the process of developping territorial cohesion (Meijers E.J., Waterhout B. W., Zonneveld A.M., 2007, Geppert K, Stephan A, 2008).

Hallgeir considers that the urban network represents the territorial system's spinal column/ spine - polycentrism ensuring the efficient and harmonious transmission of development at the level of the entire territory (Hallgeir, 2004).

Romania's polycentric development model requires a new approach of the territorial management system, through it's reorganization in accordance with the relationships between 
the categorized components of the settlements system. The polycentric development strategy represents a way of rehabilitating the areas with major structural problems, ensuring an efficient territorial management, by the spatial projection of institutional mechanisms with competences in territorial development (Peptenatu D., Pintilii R., Cepoiu L., Drăghici C., 2009, Trullén şi Boix, 2003b, Candau F., 2008).

The polycentric development model offers to the decision makers the scientific support for accomplishing major objectives of the Community Area Development Scheme (ESDP-1999): the development of a polycentric and balanced urban system and of a new urban-rural partnership, ensuring equality in terms of access to infrastructure and knowledge, sustainable development, alert management and the protection of the natural and cultural inheritance.

The most important works in the field of polarization have been written by Perroux (1955), Myrdal (1957) and Hirschmann (1958), who underline the importance of development poles in eliminating or mitigating territorial unbalances. Theoretical aspects of polarized development are also treated by Boudeville (1966) and Lasuen (1969), who developed Perroux's concept of sectorial growth poles into regional and sectorial growth poles.

Boudeville tries to translate the sectoral polarization effects with the help of Christaller's (1933) and Lösch's (1955) structural theory of location in geographical space. He starts from the assumption that sectoral polarization is connected to regional polarization, considering that sectoral growth poles resemble regional poles.

Maier K. considers polycentric development an effective way of mitigating territorial unbalance and consolidating the territorial cohesion, by the development of transport infrastructure and by supporting foreign investments (Maier K, 2009).

lanoş I. identifies two stages of regional development: the polarization or spatial concentration stage (within which an industrial urban process is developed at national level, leading to economic growth), and the integration stage, when a decentralization or a counter polarization takes place, starting from an intraregional decentralization (the industry relocalization in satellite-towns) towards an interregional decentralization (the development of some secondary centres localized in big cities) and finally reaching an intraregional decentralization (lanoş I., 2006, McCann P., Shefer D., 2004).

The demographic component is the most intolerant variable of territorial system, disturbances at the other components' level influencing the geographic dimension of local territorial systems. This strong relationship has determined the decision makers to adopt specific regional policies, at the European suprasystem level, leading to the shaping of some favorable premises of evolution at the demographic component level.

The importance of polycentric development is obvious in the case of strongly disadvantaged areas where development poles can contribute to the attenuation of economic and demographic unbalance, by the optimal spacial structure.

lanoş I. and Heller W. carry out a theoretic model of the way in which innovation cotributes to the economic growth of the territory, a model we can extrapolate to polycentric development, where development nuclei contribute to the diffusion of development towards polarized areas. In the authors' opinion, the economical dynamic is dependent especially on the fourth production factor, respectively science, know how, especially on the technological and organizational one. This dynamic depends on the scientific research, having as a premise the 
fact that science multiplies by inventions and discoveries, with a direct effect upon economy. For the economic processes to become dynamic, science and knowledge production growth implicitly must be spread, in general (lanoş I., Heller W., 2006, McCann P., Simonen J., 2005, Dijk J, Pellenbarg P.H, 2000, Broersma L., Dijk J., 2002).

\section{Working methodology}

The analysis of the territorial systems' dynamic highlights the tight connection between the demographic component and the mutations at the development poles level. The configuration of settlements systems, the different demographic evolutions represent the direct effect of some economic development policies, which have had as a result the functional structuring of geographic space subordinated to the development poles.

This study consists of a reference of the types of demographic evolution to the network of development poles structured as a result of the convergent action of favourable factors. Identifying the development poles was done based on the coefficient of polarization capacity, depending on which there were identified five categories of development poles in Romania (the capital, national poles, regional poles, interregional poles and growth poles), grouped in five decision levels (Fig.1).

This model's development was based on the theory of dissipative structures, in the interior of human settlements systems being noticed aggregation-disaggregation, concentrationdeconcentration, unbalance-functional rebalance processes, which determine a temporary optimization of relationships between its main structures. The intensity of these modifications reflects at the level of settlements systems, the more as it affects the dynamic of growth poles (lanoş I., Humeau J.B., 2000).

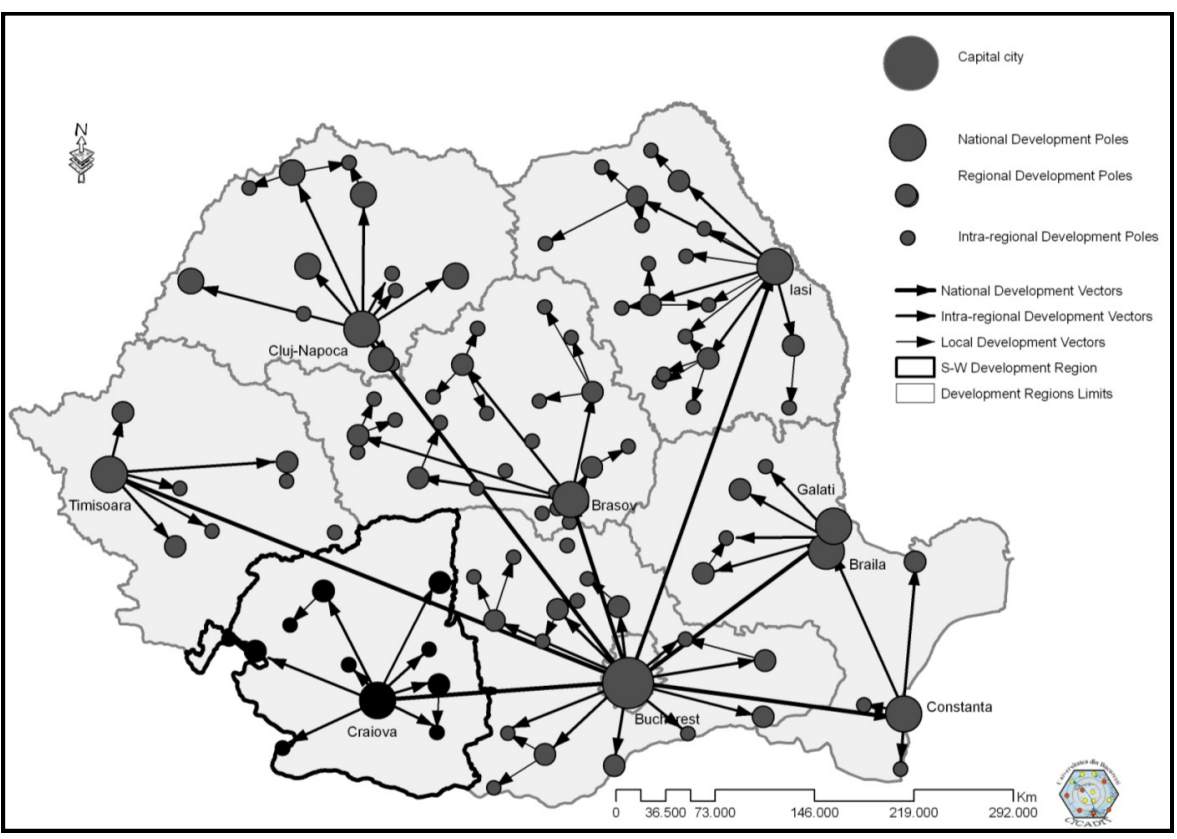

Fig.1 - Physiognomy of the national polycentric network 


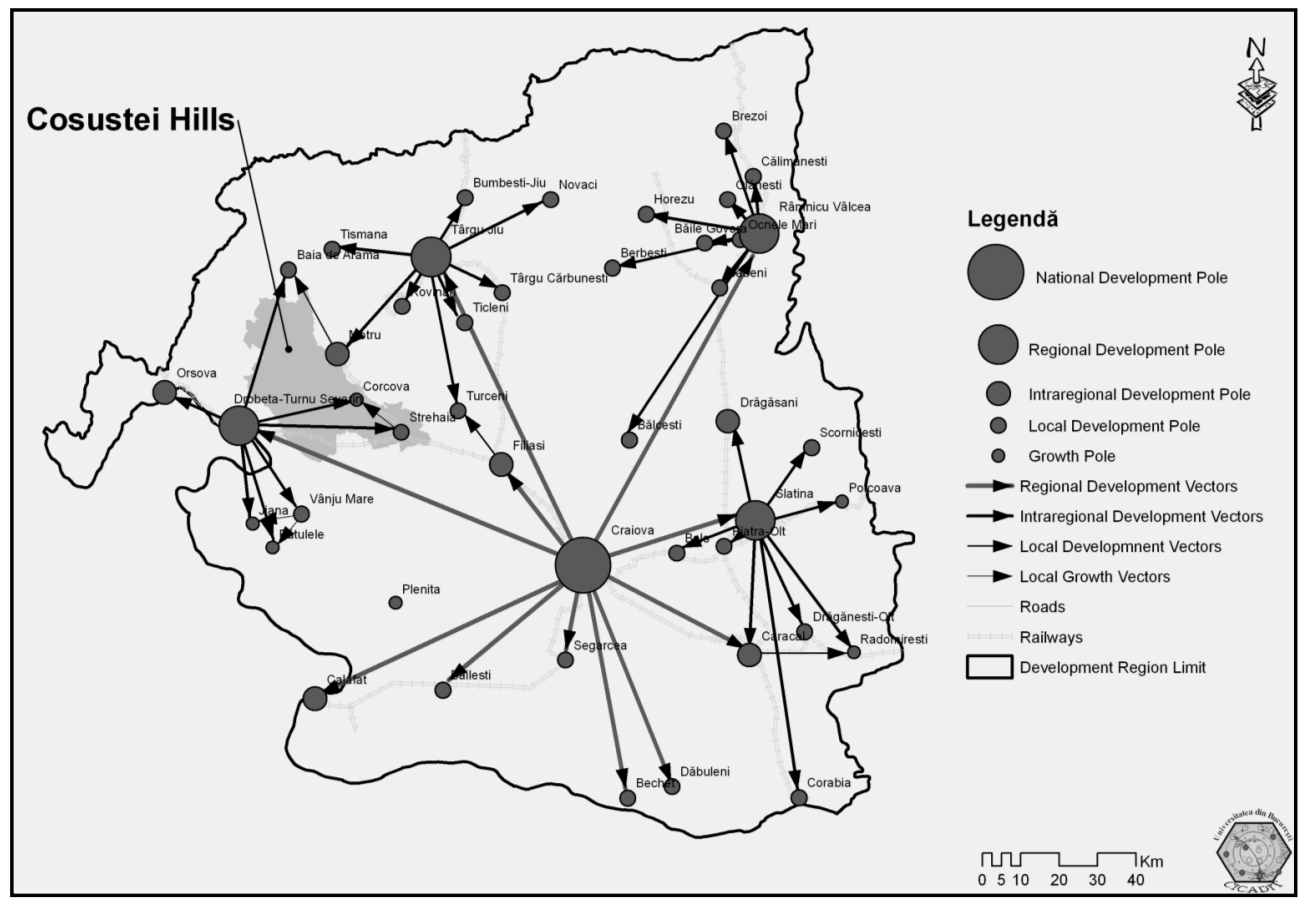

Fig. 2 - The South-West polycentric network

Identifying development poles was achieved at the level of the year 2002, starting from a complex coefficient: the coefficient of polarization capacity which includes the following criteria:

- demographic size and activity;

- $\quad$ economic strength and competitiveness;

- $\quad$ polarization capacity by means of services which belong to the superior tertiary;

- $\quad$ number of inferior rank towns from the area of influence.

The South-West polycentric network is coordinated by the town Craiova, with a value of the coefficient of polarization capacity of 53.08, at a rather large distance from regional poles Râmnicu Vâlcea - 52.24, Târgu Jiu - 52.15, Drobeta Turnu Severin - 51.96 and Slatina - 51.95 (Fig.2).

Regional poles imposed themselves within the settlements network by the development, during the communist period, of some industrial activities of national importance.

The designing of the South-West polycentric network led to identifying the profoundly disadvantaged areas, which occupy an important part from the south of the South-Western development region, where a series of development poles were individualised. This could form, in the perspective of several appropriate development policies, some local development poles.

The analysis of demographic indicators was done at the level of all the population censuses: 1912, 1930, 1948, 1956, 1966, 1977, 1992 and 2002. At each census, was trailed the way in 
which the changes detected at the development poles' level influeced the level of human settlements from the studied area.

In order to get a detailed analysis, the studied settlements were clasified in a few size categories under 250, 251-500, 501-750, 751-1000, 1001-1500, over 1501 inhabitants.

\section{Results}

The Coşuştei Hills is a representative region for two demographic processes specific for the rural areas of Romania: the depopulation of villages (Fig.3) and the demographic ageing. In the study of human settlements of this region we aimed at answering to the following questions: „How did the depopulation of these settlements happen?”, „Which are the directions of the population's movement?", "Which are the factors which contribute to the movement of population towards other settlements?" The determinant indicators of the evolution of inhabitants' number, natural movement and migratory movement determined different evolutions in the studied area, estimated on the basis of the population censuses (1912-2002). There were identified four types of demographic evolution: multiannual constantly positive evolution, multiannual sinuous generally ascendant evolution, multiannual sinuous generally descendant evolution, and multiannual constantly negative evolution.

Only two settlements recorded a constantly positive evolution, Comanda and Jirov, settlements which benefitted from the proximity of an urban centre (Strehaia for Comanda and Motru for Jirov). The favourable position of the village Jirov within the commune made this village exceed the commune seat, Corcova. In the case of the village Comanda, the evolution is also determined by the local development potential, which adds to the effect of urban proximity.

Villages which recorded a multiannual sinuous generally ascendant evolution are advantaged by the geographic position, but to a lesser extent. In this category some commune seats are

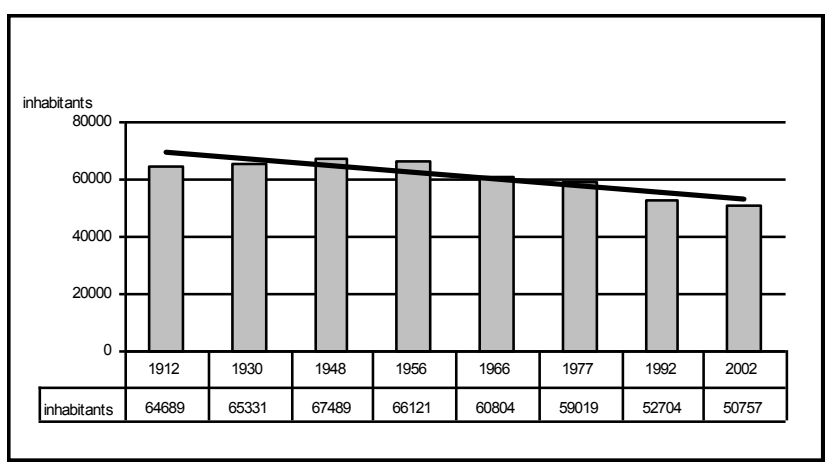

Fig.3.-The evolution of the inhabitants' number in the Coşuştei Hills

situated (Broşteni, Corcova, Floreşti), where the advantages of geographical position and those of the administrative function acted, and a series of villages advantaged by the position in relation to communication ways (Câmpu Mare, Ciochiuța, Croica, Ercea, Cordun etc.), which determined permanent movements towards these villages.

Most of the settlements from the Coşuştei Hills are positioned in the categories that have the decrease of the inhabitants' number (over $65 \%$ ) as a central element. Several settlements recorded continuous decreases of the inhabitants' number, and the authorities assume that many of these do not have development perspectives(Alunişul, Bârda, Bobaița etc.). The lack 
of perspective is determined firstly by the natural degradation of demographic potential, which numbers in some villages is under ten inhabitants and high demographic ageing coefficients. In the case of other settlements, even if they recorded the same fall, there are perspectives of demographic re-balancing, through the support of some economic activities which could help settle young population (Borogea, Crăgueşti, llovăț etc.).

A multiannual sinuous generally descendant evolution is recorded in some villages which in certain socio-economical conditions recorded an increase of the inhabitants' number; it is about the pro-natality policy of the communist period. The following villages are grouped in this category: Bădițeşti, Bala, 23 August, Brateşul, Brativoieşti, Brața, Budăneşti, Cărămidaru, Cârşu, Căzăneşti, Celnata, Cernaia, Cervenița, Ciovârnăşani, Cocorova, Colibaşi, Comăneşti, Cotoroaia, Crainici, Cremenea, Şişeşti, Şovarna.

At the 1912 census, $28.3 \%$ of the settlements had a population under 250 inhabitants, among these settlements being a commune seat, too: Floreşti (Fig.4). In the same category, there were a series of villages, namely: Măru Roşu, Croica, Prunaru, Jignița, Peşteana. In the category $251-500$ inhabitants, there were $35.7 \%$ from the settlements, from among which two commune seats: Husnicioara and Căzăneşti. In both categories there are placed peripheric settlements compared to the communes' seats.

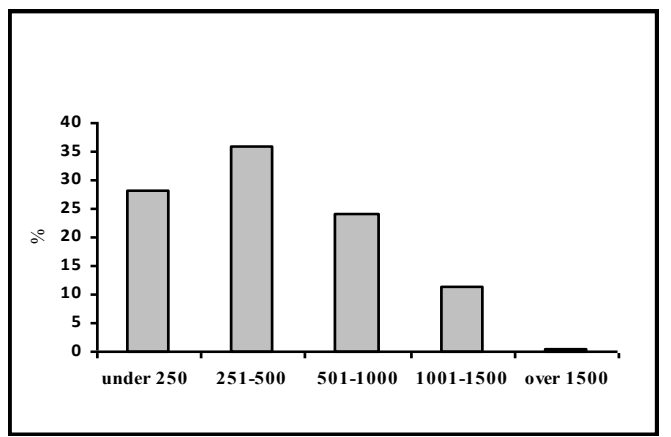

Fig. 4 - The human settlements structure by inhabitans number at the 1912 census

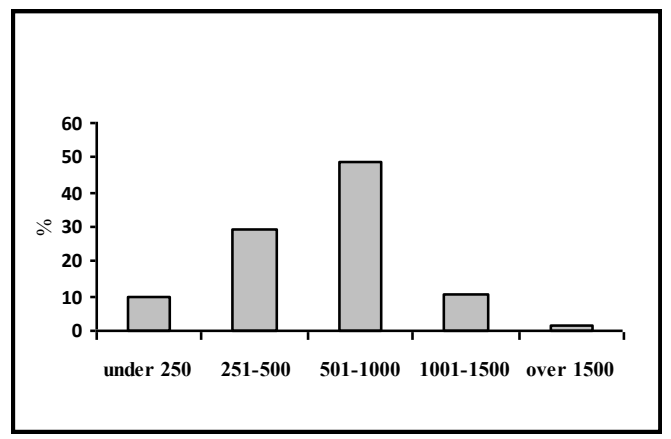

Fig. 5 - The human settlements structure by inhabitants number at the 1930 census

The category $501-1000$ gathers $24 \%$ of the settlements, among which commune seats and villages with an important local potential: Ciovârnăşani, Corcova, Broşteni, Prunişor, Voloiac, Zegujani etc. The cathegory $1001-1500$ gathers $12 \%$ of rural settlements which are the most privileged by the local potential and geographic position point of view (Comanda, Ciochiuța, Malovăt, Jirov, Şişeşti etc.).

Over 1501 inhabitants were registered in Şovarna village, which represented and still represents a local polarization centre, both for the Coşuştei Hills and the Mehedinți Plateau.

In this period, the intensity of the attraction force of development poles is reduced, there are noticed movements of the population towards the development poles Bucharest and Craiova. It is the period of an important dynamic between the settlements in this area.

The 1930 census does not mention 26 villages which became components of other rural settlements. Most of them had under 250 inhabitants, except for the villages Comanda and 
Ciochiuța (they are part of Strehaia town), which had over 1000 inhabitants each. This grouping was not successful in reviving these settlements, many of them continuing the demographic decrease. This administrative intervention has as a result the reducing to $10.1 \%$ the settlements are situated in the class under 250 inhabitants (Fig.5).

The category $251-500$ inhabitants comprises of $29.1 \%$ of the settlements. The evolution of some settlements resulted in their crossing from the first category (under 250 inhabitants) to the category 251-500 inhabitants (Suharu and Măru Roşu).

The class 501-1000 inhabitants groups, at this census, $48.8 \%$ of the settlements. The important progress of almost $50 \%$ is determined by the natality increase in some villages, but also by the demographic input of the villages administratively added to them. The Ercea village has a spectacular evolution of the inhabitants' number, from 274 in 1912 to 568 in 1930 . With few exceptions (Bala, Racova, Ohaba), all other villages recorded spectacular growth of the inhabitants' number.

Eight settlements are situated between 1001 and 1500 inhabitants, which represents 10,3\% from the settlements. The decrease is due to the moving/ passing of some settlements in the superior category (Ilovăț, Şişeşti). It is to be noticed that even if they remained in this size category, most of the villages recorded a decrease in the inhabitants' number compared to previous census. Only Crăguieşti village recorded a slight growth of the inhabitants' number, determined by the natural balance. The category of over 1501 inhabitants gathers three settlements, all of them important centres of local polarization, significant local development resources. The village Şovarna stands out through its over 1800 inhabitants, a record number for a village in this area.

In the interval 1912-1930, clear directions of the population movement towards development poles appear. A significant growth is recorded in this interval: Timişoara, Reşița, Drobeta Turnu Severin.

The 1948 census start to be recorded evidences of the demographic decline of the villages from the Coşuştei Hills.

The category under 250 inhabitants now gathers $30.5 \%$ of the human settlements. The villages Stroieşti and lupca have a major demographic decline, which makes them descend from the interval 501-1000 inhabitants.

In the category $251-500$ inhabitants there are included $28,6 \%$ of the settlements, the decrease favoring the previous group (Fig.6). Many villages fall in this category from the category $501-$ 1000 inhabitants (Imoasa, Negreşti, Căzăneşti, Govodarva, Ercea etc.). The interval 501-1000 covers $31.4 \%$ of the settlements, the diminution towards previous census being done in the favour of previous groups.

Superior intervals (1001-1500 and over 1501) record important mutations. Only one settlement (Şişeşti) exceeded 1501 inhabitants, and 9 settlements exceeded 1001 inhabitants, but the decrease of the inhabitants' number is important, these exceeding this threshold at the limit.

In this interval there are movements of the active population towards the towns Timişoara, Craiova, Reşița and Drobeta Turnu Severin.

The 1956 census shows the accentuation of the previously mentioned phenomenon. Thus, 
$27.6 \%$ of the settlements had a population under 250 inhabitants, and $34.1 \%$ of the settlements had between 251 and 500 inhabitants (Fig.7). The decrease of the inhabitants' number is general for both size intervals. The same phenomenon characterizes superior intervals, where $33.3 \%$ of the settlements have between 501 and 1000 inhabitants and only 7\% between 1001 and 1500 inhabitants. The village Şişeşti is the only one which exceeds the threshold of 1501 inhabitants, even if it has had an important decrease of the inhabitants' number.

After 1950, an accentuated process of industrial development of the centres which were regional seats (region seats and district seats) begins. They benefitted of priority in the allocation of funds for development. The overplus of jobs recorded at these development poles' level determines the circulation of population towards several towns, whereas the demographic ageing of the settlements from the Coşuştei Hills is more visible.

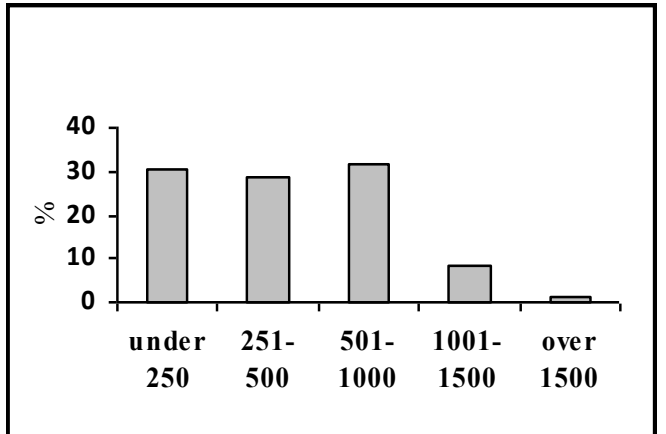

Fig. 6 - The structure of human settlements by the inhabitants' number at the 1948 census

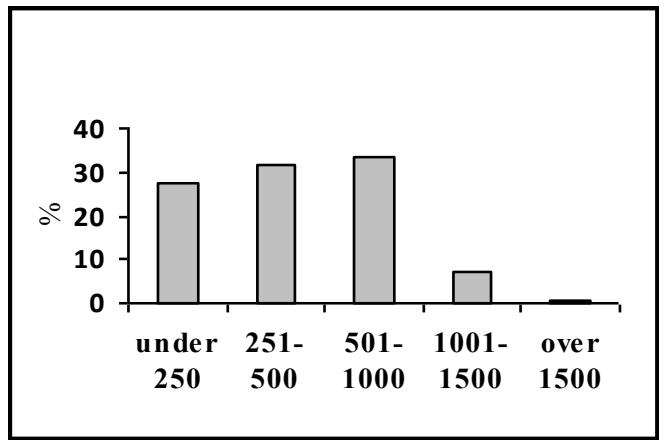

Fig. 7 - The structure of human settlements by the inhabitants' number at the 1956 census

At the 1966 census, $36.2 \%$ of the settlements had a population under 250 inhabitants, and $29.5 \%$ had between 251-500 inhabitants. Some settlements record real demographic shocks, the population being reduced with $25 \%$ compared to the previous census (Alunişu, Drăgoteşti, Roşia etc.). Within the size interval 501-1000 inhabitants, $27.6 \%$ of the villages are enclosed, and in the interval over 1001 inhabitants, which is now the last, $6.7 \%$ of the villages (Fig.8). The village Şişeşti, even if it maintains its supremacy, it descends under the threshold of 1501 inhabitants.

The accentuation of the development gaps/ differences determines the decision makers to direct, after 1970, important investments towards medium sized towns. Within this interval there is to be mentioned the attraction force of the towns Craiova, Târgu Jiu, Motru, Drobeta Turnu Severin, which impose by the deficit of workforce, which attracts active population from the settlements from the Coşuştei Hills.

The 1977 census emphasizes the high share of the villages having under 250 inhabitants (38.1\%) and between 251-500 inhabitants (27.7\%) (Fig.9). The interval 501-1000 inhabitants groups $29.5 \%$ from the settlements, many of them being from superior intervals. Over 1001 inhabitants are registered in 7 villages, the supremacy being held by the village Jirov, which hardly exceeds 1300 inhabitants.

At this census, it can be noticed the development of some settlements such as Ciochiuța, 
Comanda (near Strehaia) and Malovăț (near Dr.Tr. Severin), which „felt” the economic development of the neighbouring urban centres.

The industrial leap of development poles Craiova, Drobeta Turnu Severin, Motru, Reşița, Filiaşi, Târgu Jiu induced the accentuation of the demographic decline in the Coşuştei Hills. Permanent movements of the active population towards these centres take place. Real networks emerge, through them, opportunities of occupation within development poles are constituted.

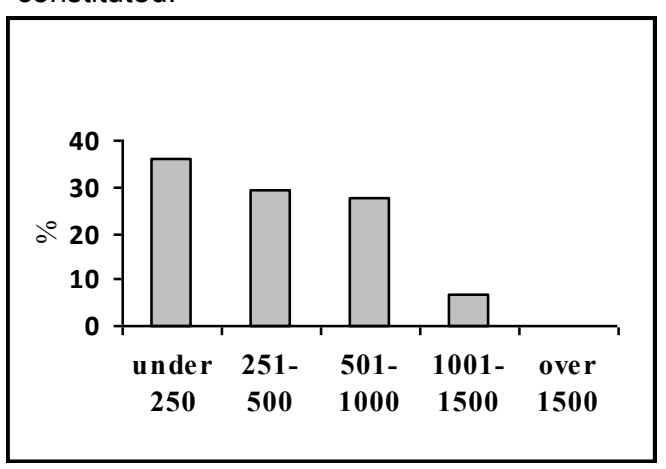

Fig. 8 - The structure of human settlements by the inhabitants' number at the 1966 census

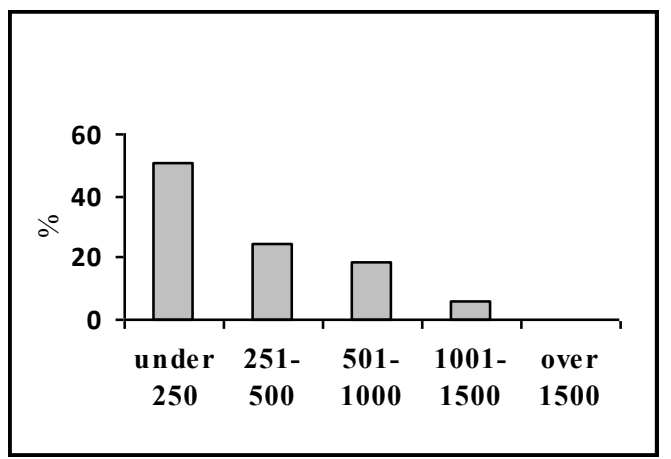

Fig. 10 - The structure of human settlements by the inhabitants' number at the 1992 census

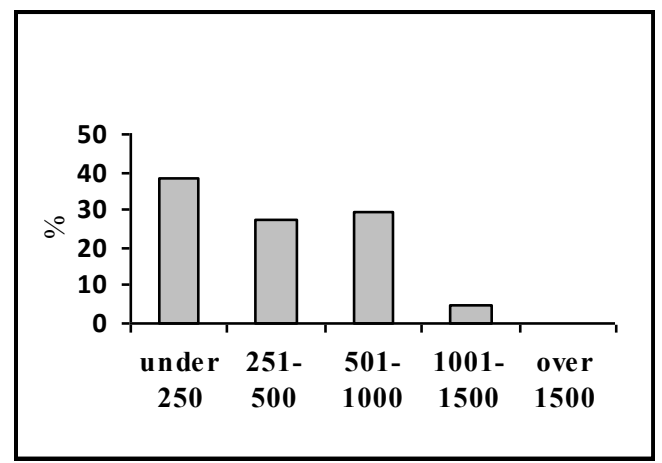

Fig. 9 - The structure of human settlements by the inhabitants' number at the 1977 census

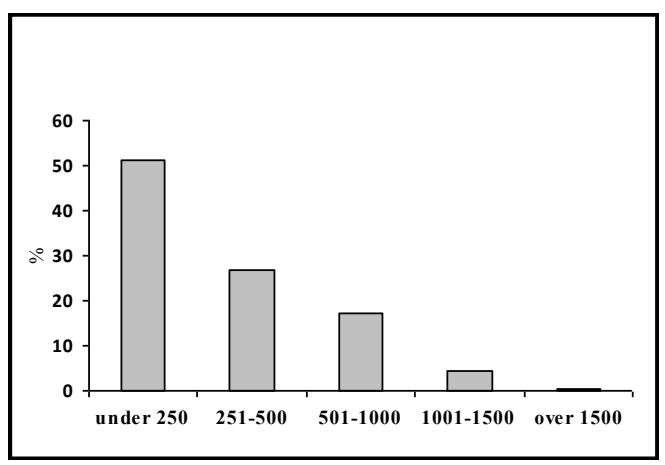

Fig. 11 - The structure of human settlements by the inhabitants' number at the 2002 census

The 1992 census shows the major demographic decline recorded in this area where $50.5 \%$ of the settlements have a population under 250 inhabitants, and $24.5 \%$ have a population between 251 and 501 inhabitants (Fig.10). Only 19\% is represented by villages with a population between 501 and 1000 inhabitants. Over 1001 inhabitants are registered in only 6 villages, whereas in 4 of the villages the population is decreasing. The village Comanda holds the first place due to the increase of the inhabitants' number. A less spectacular increase is registered by the village Jirov, due to the natural balance recorded by the gipsies' community.

After 1980, industrial enterprises are opened in all small towns. A new stage of industrialisation of rural localities in the perspective of their transformation into urban centres begins. The 
investments done at the level of the communes Căzăneşti, Corcova, Broşteni, Şişeşti, Malovăt determine the reduction of the active population movement towards development poles. The exceptions are the movements towards Bucharest and Timisoara, which maintain at high values.

The last census, the one from 2002, shows the growth of the percentage of the villages under 250 inhabitants, which reaches $51.4 \%, 13.3 \%$ of the villages having a population of under 100 inhabitants (Fig.11). Next interval (251-500 inhabitants) registers a significant growth, weighing $26.7 \%$. The villages with a popualtion between $501-1000$ inhabitants represented only $17.1 \%$ from the total of settlements. In the same note, superior categories are grouped, where only 5 villages had a population over 1001 inhabitants, and of these, only one village has over 1501 inhabitants (Jirov).

From the detailed analysis presented above, it can be noticed the general tendency of growth of the number of villages with a population under 250 inhabitants and of those between 251 and 500 inhabitants. The evolution is determined by the lack of resources and of capitalization of the existent ones on local scale, and also by the attraction exerted by urban polarizing centres.

Industrial destructuring registered after 1990, at the level of development poles, leads to profound mutations at the level of human settlements from the Coşuştei Hills.

The previous evolution of the polarized development process contradicts economic theories of attenuating territorial unbalance by sustaining development poles, the increased imbalance being obvious. This phenomenon takes place when these poles have a reduced capacity of diffusing development towards the subordinated area. In the studied area, the action of development poles Drobeta Turnu Severin and Motru is obvious. Through their economic structure, these two development poles succeed to diffuse information in the territorial systems from the Coşuştei Hills, and consequently to contribute to the functional restructuring of space.

Even if the process of development diffusion is incipient, the process is evident in the higher and higher consistency of investments achieved in the Coşuştei Hills in economic activities which serve the two polarizing centres. It must be added that the population from the two development poles is interested in returning to the villages with a good accessibility.

Although these tendencies are well contoured, the intensity of these processes cannot balance the depopulation and demographic ageing processes. In isolated territorial systems, these processes exceeded the critical level and they remained dominant, variable components of the system being unable to react to external decisional impulses.

The perspective of developing a regional polycentric network will create the premises of information diffusion from the level of development poles Drobeta Turnu Severin, Motru, Strehaia, Baia de Aramă, Târgu Jiu towards certain territorial systems from the Coşuştei Hills, which benefit from a series of advantages determined by the favourable position towards main transport axes. The settlements Corcova, Sişeşti, Broşteni, Malovăț, Ilovăț are in this situation.

\section{Conclusions}

The systemic approach of human settlements from the Coşuştei Hills highlights the extent to which the transformations from the development poles level influence rural systems, most of them affected by depopulation and demographic ageing. 
The studies of the relationship between processes at the development poles level and the subordinated localities underline the direct dependence relationship.

Before 1989, the relationship between development poles and the settlements from the Coşuştei Hills were strongly influenced by the agriculture cooperativization, socialist industrialization and the orientation of resources towards megalomanic projects. Also, these relationships' structure was determined by the historical proportion between resources, population and infrastructure quality (lanoş I. and Heller W., 2006).

During the communist period, development poles registered a diversification and functional enlargement which determined the attraction of potential and human capital from the subordinated rural settlements, which confront a functional reduction. The agriculture's cooperativization determines the reduction of personnel for an important percentage from the occupied population from agriculture.

The local settlements network from the Coşuştei Hills records important decisional impulses in the period 1948-1950, when central authorities direct big investments at the level of regional centres. It is the period when the town Craiova records an important deficit of work power, which is covered especially from the rural area (Fig.12).

The town Motru is founded on an empty land, in order to coordinate the mining activity from this area. It is the town which attracted, with different intensities, the active work power from the rural settlements around.

After 1970, the policy of the centralised state is oriented towards investments in small and medium sized towns, under the circumstances of increased attraction forces and the accentuation of demographic decline. The towns Strehaia, Baia de Aramă, Filiaşi add to other development poles and contribute to rural settlements impoverishment with regards to active population (Fig.12).

After 1980, an ample small towns industrialization process begins, aiming at consolidating their position within the local settlements systems. In these conditions, forces exerted by the well known development poles diminish. In the studied area, the towns Baia de Aramă and Strehaia develop, and around the communes Malovăț, Corcova, Broşteni, they contribute to the reduction of migratory flows towards major development poles.

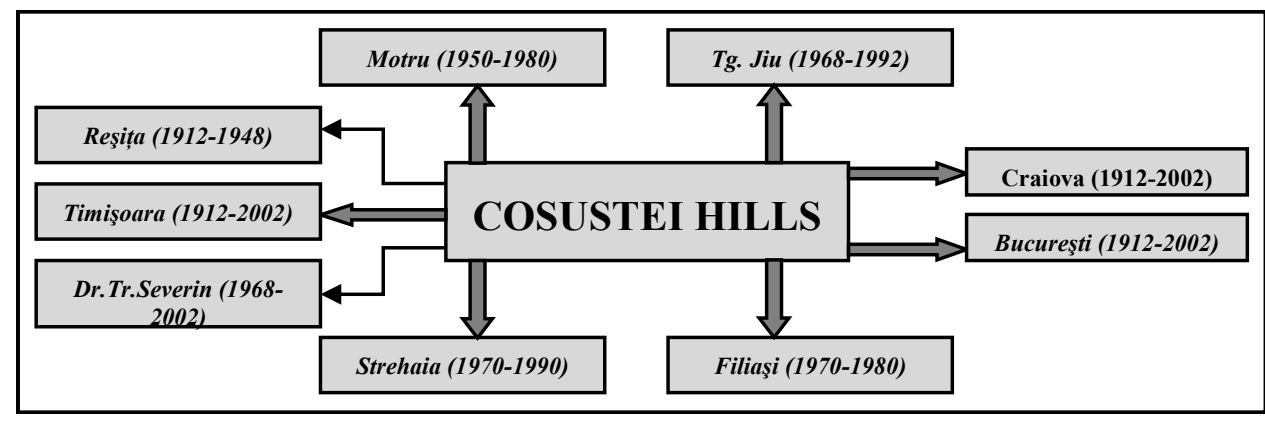

Fig.12 - Orientation of the population flows

The radical modification of the socio-economic system from 1989 led to a confusion of the human settlements system, under the impulse of populist measures from the transition period. 
The years 1990-1991 are characterised by an increase of the number of employees in the industrial sector, although national economy gives clear signs of decline. During those years, the number of exits from the studied area increase significantly. Between 1992-1999 a collapse of national economy takes place, first reductions within employees sector appear, as well as first population displacements from the polarising centres towards rural area.

The reduction of subsidies in the mining industry determined the dramatic reduction of this activity and consequently of the regional importance of the town Motru, as many recent unemployed return to rural area.

After the year 2000, a new vigor of national economy is felt especially at the level of towns. The flows of migration towards development poles are continued especially to Bucharest, Craiova, Motru, Drobeta Turnu Severin and Timişoara.

There can be noticed the functional restructuring of territorial systems near the towns Drobeta Turnu Severin and Motru, which benefit from a series of private investments in economic activities which serve for these towns situated in full economic development.

The development of polycentric network in the South-Western Development Region may contribute to systems' revitalization by creating positive imbalance, which then, by propagation effect, would support the development of all territorial systems.

The development perspectives of the settlements from the Coşuştei Hills are connected to the decision factors' capacity to restructure the territorial management system according to the new European context, and to promote pragmatic, sustainable, coherent development policies in the area, at a level which could ensure the systems' revitalization, and even the transformation of some of them into growth centres.

The preoccupation of the decision makers for the consolidation of the regional polycentric network, will lead to the structuring of an efficiet system of transmitting the innovations and good practices from the European suprasystem's level to the local level, this way contributing to the rehabilitation of rural systems which benefit from a local context, favourable to development.

\section{References}

BOIX R, TRULLÉN J. (2007), Knowledge, networks of cities and growth in regional urban systems, Papers in Regional Science, 86, p.551-574.

BOUDEVILLE J.R. (1966), Problems of Regional Economic Planning, Edinburgh University Press, Edinburgh

BROERSMA L., DIJK J. (2002), Regional labour market dynamics in the Netherlands, Papers in Regional Science, 81, p.343-364.

CANDAU F. (2008), Good governance, trade and agglomeration, Papers in Regional Science, 87, p. 483-504.

DIJK J., PELLENBARG P.H. (2000), Firm relocation decisions in The Netherlands: An ordered logit approach, Papers in Regional Science, 79, p.191-219.

GEPPERT K., STEPHAN A. (2008), Regional disparities in the European Union: Convergence and agglomeration, Papers in Regional Science, 87, p.193-217.

HALLGEIR A. (2004), Spatial policies in the European Union, EuroFutures, Stockholm. HIRSCHMANN A.D. (1958), The Strategy of Economic Development, New Haven, London. 
IANOŞ I., HELLER W. (2006), Spațiu, economie şi sisteme de aşezări, Editura Tehnică, Bucharest.

IANOŞ I., HUMEAU J.B. (2000), Teoria sistemelor de aşezări, Editura Tehnică, Bucharest.

LASUEN J.R. (1969), On Growth Poles, Urban Studies, 6, p.137-161.

MAIER K. (2009), Polycentric development in the spatial development policy of the Czech Republic, Urban Research \& Practice, 3, p.319 - 331.

MCCANN P., SHEFER D. (2004), Location, agglomeration and infrastructure, Papers in Regional Science, 83, p.177-196.

MCCANN P., SIMONEN J. (2005), Innovation, knowledge spillovers and local labour markets, Papers in Regional Science, 84, p.465-485.

MEIJERS E.J., WATERHOUT B.W., ZONNEVELD A.M. (2007), Closing the GAP: Territorial Cohesion through Polycentric Development. European Journal of Spatial Development, 24, p. 1-24.

MYRDAL G.M. (1957), Economic Theory and Under Developed Regions, Gerald Duckword, London.

PEPTENATU D., PINTILII R.D., CEPOIU L., DRĂGHICI C. (2009), Polycentric development strategy - an efficient instrument in administrative decentralization, Romanian Review on Political Geography, 2, p. 99-111.

PERROUX F. (1955), Note sur la notion de pole de croissance, Economique appliqué,12, p.307-320.

TRULLEN J., BOIX R. (2003a), Knowledge, networks of cities and growth in regional urban systems, Working Paper 05.04 Departament d'Economia Aplicada, Universitat Autònoma de Barcelona.

TRULLEN J., BOIX R. (2003b), Barcelona, polycentric metropolis and network of cities, REAL CORP 008, Viena.

WANG X., KOCKELMAN K.M. (2009), Application of the dynamic spatial ordered probit model: Patterns of land development change in Austin, Texas, Papers in Regional Science, 88, p.345-365.

WU F (1998), Polycentric urban development and land-use change in a transitional economy: the case of Guangzhou, Environment and Planning A 30, p.1077-1100.

Received at : 10.02 .2010

Revised at: 15.04.2010

Accepted for publication at: 20.05.2010 